\title{
MEMOIRS of the
}

\section{Society for American Archaeology}

Number Seventecn

\section{PREHISTORIC AGRICULTURE AT POINT OF PINES, ARIZONA}

\author{
RICHARD B. WOODBURY
}

PUBLISHED BY THE SOCIETY FOR AMERICAN ARCHAEOLOGY 


\section{THE SOCIETY FOR AMERICAN ARCHAEOLOGY}

President: ERIK K. Reed, 238 Griffin St:; Santa Fe, N. M.

President-Elect: Junius B. BiRD, American Museum of Natural History, Central Park West at 79th St., New York 24, N.Y.

Secretary: Joe Ben Wheat, University of Colorado Museum, Boulder, Colo.

Treasurer: James L. Swauger, Carnegie Museum, Pittsburgh 13, Pa.

Executive Committee Members: WILliam R. Coe (to 1961), University Museum, Philadelphia 4, Pa.; RoberT H. Lister (to 1961), Department of Anthropology, University of Colorado, Boulder, Colo.; Ignacio Bernal (to 1962), Tres Picos 65, Mexico 5, D.F.; Charles E. Borden (to 1962), Department of Anthropology and Sociology, Division of Archaeology, University of British Columbia, Vancouver 8 , B.C.

Editor: Raymond H. Thompson, Department of Anthropology, University of Arizona, Tucson, Ariz.

Editor of "Abstracts of New World Archaeology": Richard B. WoodBury, Department of Anthropology, University of Arizona, Tucson, Ariz.

Editor of "Archives of Archaeology": David A. Baerreis, Department of Anthropology, Sterling Hall, University of Wisconsin, Madison 6, Wisc.

Associate Editor for Reviews: Donald Collier, Chicago Natural History Museum, Chicago 5, IIl.

Associate Editor for Notes and News: Nathalie F. S. Woodbury, Arizona State Museum, Tucson, Ariz.

Assistant Editors: ARCTIC - John M. CAMPBEll, Dept. of Soc. and Anthro., George Washington Univ., Washington 6, D.C.; CALIFORNIA - FranCIS A. RIDDELL, History Sec., State Div. of Beaches and Parks, Box 2390, Sacramento 11, Calif.; CARIBBEAN - Patrick Gallagher, Dept. of Anthro., Yale Univ., New Haven, Conn.; GREAT BASIN - William J. Wallace, Dept. of Anthro., Univ. of Southern California, Los Angeles 7, Calif.; HIGHLAND SOUTH AMERICA - JoHn H. Rowe, Dept. of Anthro., Univ. of California, Berkeley 4, Calif.; LOWLAND SOUTH AMERICA - BeTTY J. MEggers, U.S. National Museum, Washington 25, D.C.; MIDDLE AMERICA - H. B. Nicholson, Dept. of Anthro. and Soc., Univ. of California, Los Angeles 24, Calif.; NORTHEAST - Alfred K. Guthe, Rochester Museum of Arts and Sciences, Rochester, N.Y.; NORTHERN MISSISSIPPI VALLEY — WARREN L. WITTRY, Illinois State Museum, Springfield, Ill.; NORTHWEST - CharL Es E. Borden, Dept. of Anthro. and Soc., Div. of Archaeology, Univ. of British Columbia, Vancouver 8, B.C.; PLAINS - Robert L. StePhenson, River Basin Surveys, 1517 O Street, Lincoln 8, Neb.; SOUTHEAST - Charles H. FairbanKS, Dept. of Anthro., Florida State Univ., Tallahassee, Fla.; SOUTHWEST William W. Wasley, Arizona State Museum, Tucson, Ariz.

Editorial Assistant: Molly K. Thompson, 2637 N. Plumer Ave., Tucson, Ariz.

AmERICAN ANTIQUity publishes original papers on the archaeology of the New World and closely related subjects. Articles and "Facts and Comments" should be submitted to the Editor, publications for review to the Associate Editor for Reviews, and information for "Notes and News" to the appropriate Assistant Editor. American AnTIQUITY is not available for exchange.

American Antrouity is published quarterly in July, October, January, and April by the Society for American Archaeology at the University of Utah Press, Snlt Lake City 12, Utah. Entered as secondclass matter June 1, 1951, at the Post Office, Salt Lake City, Utah, under the Act of March 3, 1879. Subscription is by membership in the Suciety for American Archaeology; annual dues are \$8.00, of which $\$ 7.00$ are for a subscription to AMERICAN ANTrQuity and other regular publications of the Society as issued. Address requests for membership or other information to the Secretary. Send instructions for change of address to Society for American Archaeology, 1530 P Street, N.W., Washington 5, D.C. See inside back cover for information on ordering back issues of AMERICAN ANTIRUITY and other publications of the Society which are still in print. 


\section{MEMOIRS OF THE \\ SOCIETY FOR AMERICAN ARCHAEOLOGY}

Number Seventeen

RAYMOND H. THOMPSON, Editor

AMERICAN ANTIQUITY

Volume 26, Number 3, Part 2

January, 1961 


\section{Prehistoric Agriculture}

\section{at Point of Pines, Arizona}




\section{PREHISTORIC AGRICULTURE AT POINT OF PINES, ARIZONA}

RICHARD B. WOODBURY

NUMBER 17

MEMOIRS OF

THE SOCIETY FOR AMERICAN ARCHAEOLOGY

SALT LAKE CITY

1961 
CONTRIBUTIONS TO POINT OF PINES ARCHAEOLOGY

NUMBER 16

UNIVERSITY OF UTAH PRESS

SALT LAKE CITY, UTAH 


\section{Contents}

Page

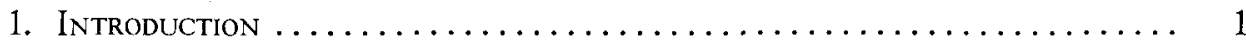

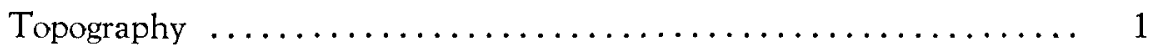

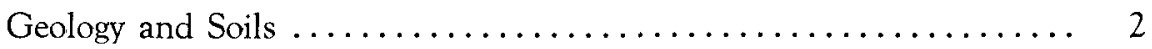

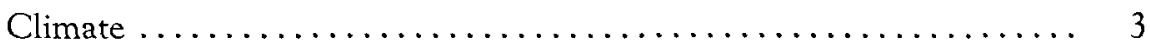

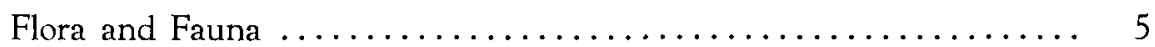

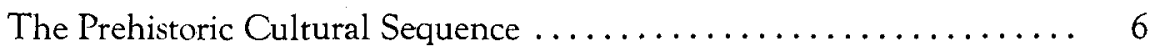

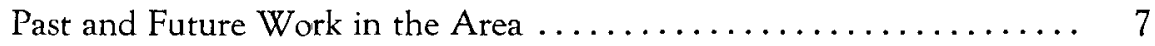

Scope and Nature of the Present Study ................... 7

2. The Types of Evidence for Prehistoric

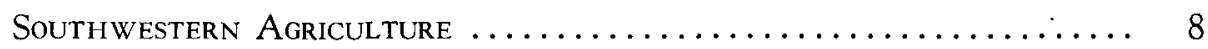

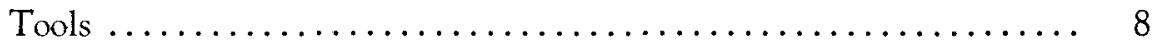

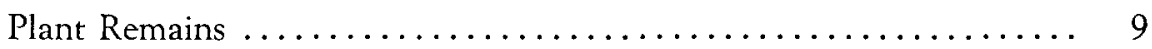

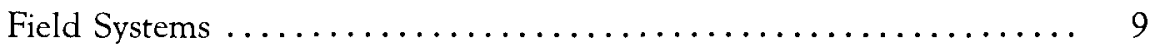

3. A Classification of the Prehistoric Field Systems and Associated Remains at Point of Pines .................. 11

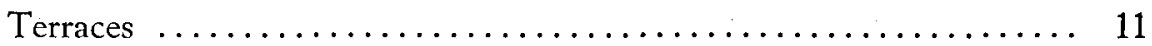

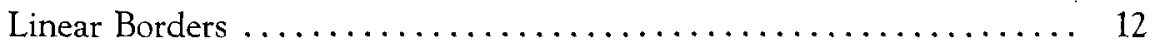

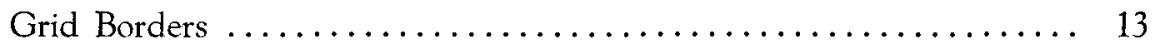

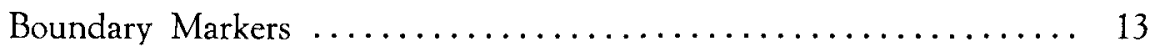

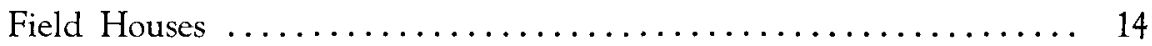

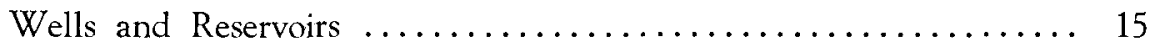

4. Description of the Farming Sites $\ldots \ldots \ldots \ldots \ldots \ldots \ldots \ldots \ldots \ldots \ldots$

Arizona $W: 9: 30$, Clover Park Site . . . . . . . . . . . . . . 17

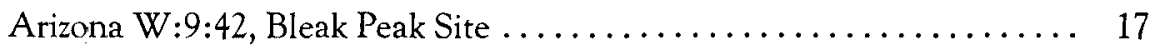

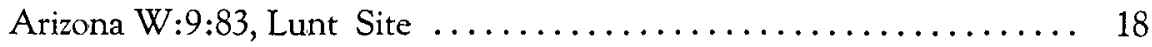

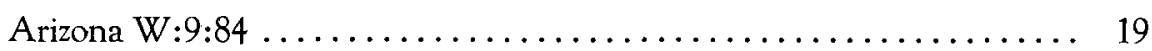

Arizona W:10:8, Salt Shed Tank Site ................. 20

Arizona $W: 10: 108$, Rocky Point Farm Site ............... 21

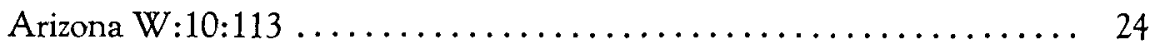

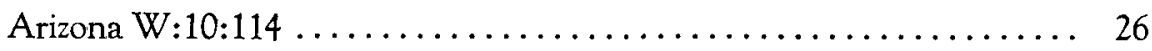

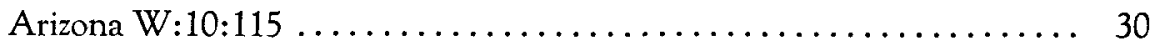

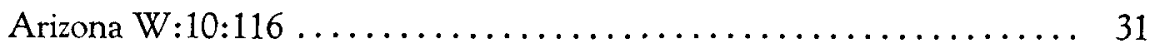


5. SUMMARY, COMPARISONS, AND DISCUSSION .................................... Page

5. Summary, Comparisons, and Discussion . . . . . . . . . . . . . . 35

The Crops Grown . . . . . . . . . . . . . . . . . . . . . . 35

The Types of Fields . . . . . . . . . . . . . . . . . . . . . 35

Antiquity of the Field Systems $\ldots \ldots \ldots \ldots \ldots \ldots \ldots \ldots \ldots \ldots \ldots$

The Acreage Cultivated ...................... 37

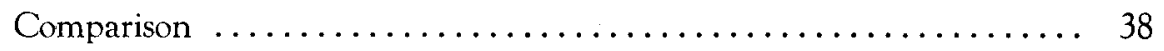

Implications and Questions . . . . . . . . . . . . . . . . . 41

Water Use in the Prehistoric Southwest ................. 43

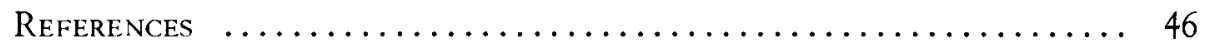

Figure

\section{ILLUSTRATIONS}

Page

1. Map showing the location of prehistoric farms in

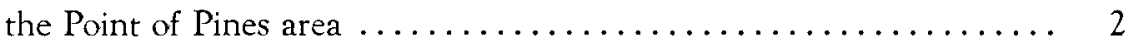

2. Generalized geological map of the Point of Pines area $\ldots \ldots \ldots \ldots \ldots \ldots$

3. Map of Arizona W:9:30, Clover Park site ................ 17

4. Remains of linear borders at Arizona W:9:30 ............... 18

5. Map of linear borders at Arizona W:9:83, Lunt site ............ 19

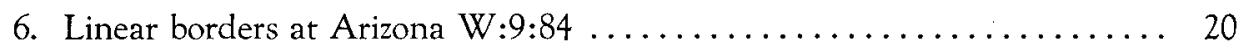

7. A linear border at Arizona W:9:84 .................... 21

8. Map of Arizona W:10:108, Rocky Point Farm site $\ldots \ldots \ldots \ldots \ldots \ldots .22$

9. Linear and grid borders at Arizona $W: 10: 108 \ldots \ldots \ldots \ldots \ldots \ldots \ldots . \ldots \ldots$

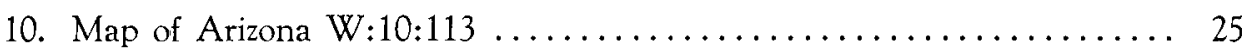

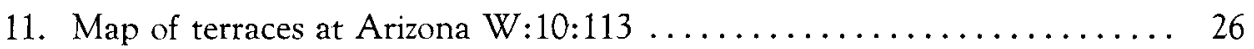

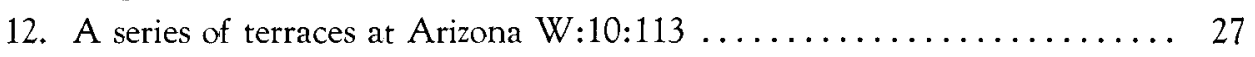

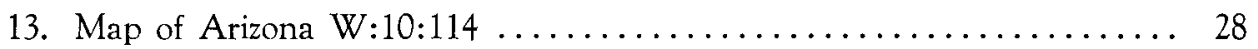

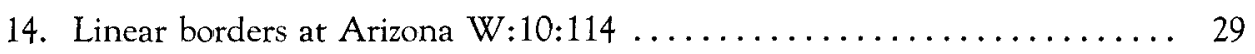

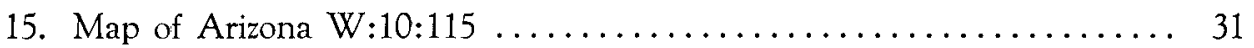

16. Map of Arizona W:10:116 ......................... 32

TABLES Page

1. The sequence of phases at Point of Pines $\ldots \ldots \ldots \ldots \ldots \ldots \ldots \ldots \ldots$

2. Measurements of terraces at Arizona W:10:113 .............. 24

3. Measurements of linear borders and terraces at Arizona W:10:114 ..... 27

4. Comparison of ten agricultural sites near Point of Pines ............ 33 